\title{
Effects of prolonged alcohol administration and a high carbohydrate-low protein diet on the activities of the jejunal brush border enzymes in the rat
}

\author{
F RAUL, ${ }^{*}$ M DOFFOEL, J MARESCAUX, R BOCKEL, and J F GRENIER
}

From the Unité 61 de l'Inserm, Strasbourg-Hautepierre, and the Service d'Hépatogastroentérologie, Clinique Médicale B, Hôpital Civil, Strasbourg, France

SUMMARY The effects of prolonged alcohol administration were studied on the brush border enzyme activities of the jejunum in rats receiving either a normal laboratory diet or a high carbohydrate-low protein diet for several weeks. Alcohol $(15 \%)$ given in association with the normal diet provoked a stimulation of sucrase, maltase, and lactase activities after four weeks, but no significant modification in aminopeptidase activity. These results obtained for the disaccharidases were very similar to those observed with the high carbohydrate-low protein diet given without alcohol, although major differences were obvious in the timing of enzyme stimulation. In contrast, this dietary condition initiated a drop in aminopeptidase activity. When alcohol was given in association with the high carbohydrate-low protein diet, no modification in aminopeptidase activity was detected and the stimulation for the disaccharidase activities was similar to that observed with the high carbohydrate-low protein diet given alone. The present results suggest that the mechanisms involved in the stimulation of brush border disaccharidase activities were different for alcohol and for the high carbohydrate-low protein diet.

It has been reported that prolonged alcohol ingestion provokes decreased activities of intestinal disaccharidases, alkaline phosphatase, and aminopeptidase.$^{1-4}$ Furthermore, chronic alcoholism in humans is known to be associated with intestinal malabsorption of a number of substances including folic acid, thiamine, vitamins, amino-acids, and D-xylose. ${ }^{5}$ These intestinal disturbances observed in alcoholics have been generally attributed to associated malnutrition. ${ }^{6-8}$

In the present paper we have compared the effects of alcohol administration to rats fed either a normal equilibrated diet or a high carbohydrate-low protein diet for several weeks on the activities of brush border enzymes of the jejunum. This study was undertaken in order to ascertain whether chronic alcohol ingestion and associated protein malnutrition may exert a synergistic effect on brush border enzyme activities which are involved in the final phase of protein and carbohydrate digestion.

\footnotetext{
* Address for correspondence: Dr Francis Raul, Unité 61 de l'Inserm, Avenue Molière, 67200 Strasbourg-Hautepierre, France.

Received for publication 15 February 1982
}

\section{Methods}

FEEDING PROCEDURE AND ALCOHOL

ADMINISTRATION

Seventy-two male Wistar rats weighing between 250 and $300 \mathrm{~g}$ were randomly divided into two equal groups: group I receiving water ad libitum, group II receiving a $15 \%$ solution of ethanol. The alcohol consumption varied from $15 \mathrm{ml}$ to $20 \mathrm{ml} / \mathrm{rat} /$ day during the whole experimental period after an adaptation period of three days. Each group was subdivided into two subgroups, A and B: subgroup A (IA and IIA) were fed a normal laboratory diet; subgroup B (IB and IIB) were fed a high carbohydrate-low protein diet. The diets were isocaloric and the rats ate their entire daily allowance of each diet $(20 \mathrm{~g} / \mathrm{rat})$. The exact composition of the diets is shown in Table 1.

EXPERIMENTAL TECHNIQUES

In each subgroup, six animals were killed two, four and eight weeks after initiation of the feeding procedure between 9 and $11 \mathrm{am}$. The abdominal cavity was opened and a $10 \mathrm{~cm}$ segment of the 
Table 1 Composition of diets

\begin{tabular}{|c|c|c|c|c|c|}
\hline \multirow[b]{2}{*}{ Diet } & \multicolumn{5}{|c|}{ Dietary components } \\
\hline & $\begin{array}{l}\text { Protein } \\
\text { (g) }\end{array}$ & $\begin{array}{l}\text { Starch } \\
\text { with } \\
\text { sucrose } \\
(70 \%) \\
(g)\end{array}$ & $\begin{array}{l}\text { Fat } \\
(g)\end{array}$ & $\begin{array}{l}\text { Salt } \\
\text { and } \\
\text { vitamin } \\
\text { mix } \\
(\mathrm{g})\end{array}$ & $\begin{array}{l}\text { Cellulose } \\
\text { fibre } \\
(\mathrm{g})\end{array}$ \\
\hline Normal (A) & $23 \cdot 5$ & $49 \cdot 8$ & $5 \cdot 0$ & $5 \cdot 7$ & $4 \cdot 0$ \\
\hline $\begin{array}{r}\text { High carbohydrat } \\
\text { low protein (B) }\end{array}$ & 5.0 & $68 \cdot 3$ & $5 \cdot 0$ & $5 \cdot 7$ & $4 \cdot 0$ \\
\hline
\end{tabular}

Values for diet are given as amounts per $100 \mathrm{~g}$ of diet. The caloric value of each diet was 69 calories/rat/day. The caloric value of the diet with $15 \%$ ethanol was 88 calories/rat/day.

jejunum extending from the ligament of Treitz was excised. Each segment was flushed with $0.9 \%$ saline. The mucosa was scraped and homogenised in 50 $\mathrm{mM}$ mannitol, $2 \mathrm{mM}$ Tris ( $\mathrm{pH}: 7 \cdot 1)$. Brush border membranes were isolated from mucosal homogenate as described previously. ${ }^{9-10}$ The following enzyme activities were determined; sucrase and maltase were assayed according to Messer and Dahlqvist, ${ }^{11}$ aminopeptidase according to Maroux et $a l^{12}$ using L-alanine-p-nitroanilide as substrate. Lactase was measured in the presence of $p$-chloromercuribenzoate. ${ }^{13}$ Proteins were assayed according to the method of Lowry et al. ${ }^{14}$

Pieces of jejunum were removed for histological examination. The height of the villi was determined using a semi-automatic quantitative image analyser (MOP. AM 01 System). Student's $t$ test was used to determine significant differences between treatment means.

\section{Results}

EVOLUTION OF BODY WEIGHT, BRUSH BORDER AND MUCOSAL PROTEIN CONTENT

The effects of the various experimental conditions on body weight and on protein content of brush border membranes are given respectively in Table 2 and 3. It can be noted that ethanol consumption (group IIA) inhibited the weight gain observed with the normal diet (group IA). However, under this dietary condition, rats receiving $15 \%$ ethanol did not present a decreased body weight when compared with the initial weight, but rather a maintenance of this latter during eight weeks.

In contrast, the high carbohydrate-low protein diet in group IB provoked an initial drop in the body weight of the rats. The weight first reached a plateau during four weeks and then increased to the level of the initial weight by eight weeks. When
Table 2 Evolution of body weight expressed as percentage of initial weight after two, four and eight weeks of different dietary conditions

\begin{tabular}{|c|c|c|c|}
\hline \multirow{2}{*}{$\begin{array}{l}\text { Diets and } \\
\text { groups }\end{array}$} & \multicolumn{3}{|l|}{ Weeks } \\
\hline & 2 & 4 & 8 \\
\hline \multicolumn{4}{|l|}{ Normal } \\
\hline $\begin{array}{l}\text { IA } \\
\left(\mathrm{H}_{2} \mathrm{O}\right) \\
\text { IIA } \\
(+15 \% \text { ethanol })\end{array}$ & $\begin{array}{l}115 \cdot 06 \pm 2 \cdot 67 \\
(n=6) \\
107 \cdot 53 \pm 1 \cdot 89 \\
(n=6)\end{array}$ & $\begin{array}{l}131 \cdot 52 \pm 2 \cdot 78 \\
(n=6) \\
108 \cdot 59 \pm 1 \cdot 48 \\
(n=6)\end{array}$ & $\begin{array}{l}147 \cdot 85 \pm 2 \cdot 57 \\
(n=6) \\
109 \cdot 22 \pm 2 \cdot 67 \\
(n=6)\end{array}$ \\
\hline \multicolumn{4}{|c|}{ High carbohydrate-low protein } \\
\hline $\begin{array}{l}\text { IB } \\
\left(\mathrm{H}_{2} \mathrm{O}\right) \\
\text { IIB } \\
(+15 \% \text { ethanol })\end{array}$ & $\begin{array}{l}87 \cdot 47 \pm 2 \cdot 48 \\
(\mathrm{n}=6) \\
82 \cdot 45 \pm 1 \cdot 79 \\
(\mathrm{n}=6)\end{array}$ & $\begin{array}{l}88 \cdot 20 \pm 2 \cdot 22 \\
(\mathrm{n}=6) \\
80 \cdot 60 \pm 3 \cdot 75 \\
(\mathrm{n}=6)\end{array}$ & $\begin{array}{l}98 \cdot 51 \pm 3 \cdot 38 \\
(n=6) \\
79 \cdot 46 \pm 1.96 \\
(n=6)\end{array}$ \\
\hline
\end{tabular}

ethanol was associated with the high carbohydratelow protein diet (group IIB), a decrease of the body weight was also immediately noted and this low level was maintained during the whole experimental period.

In comparison with the rats fed the normal diet (IA), all the three groups exhibited a $20 \%$ shortening of the villus by eight weeks in the proximal jejunum. Furthermore, there was no alteration in the morphology of the intestinal epithelial cell in the different conditions tested (results not shown).

As far as the protein content of the brush border membranes is concerned (Table 3 ), it is noted that neither the high carbohydrate-low protein diet (IB) nor ethanol administered with the normal diet (IIA) modified the amount of protein obtained after isolation of the brush border membranes as compared with group IA. The stability of the brush border membrane proteins which was obtained by eight weeks despite the shortening of the villus

Table 3 Evolution of protein content ( $\mathrm{mg}$ ) of jejunal brush border membranes isolated after two, four and eight weeks of various dietary conditions

\begin{tabular}{|c|c|c|c|}
\hline \multirow{2}{*}{$\begin{array}{l}\text { Diets and } \\
\text { groups }\end{array}$} & \multicolumn{3}{|l|}{ Weeks } \\
\hline & 2 & 4 & 8 \\
\hline \multicolumn{4}{|l|}{ Normal } \\
\hline $\begin{array}{l}\text { IA } \\
\left(\mathrm{H}_{2} \mathrm{O}\right) \\
\text { IIA } \\
(+15 \% \text { ethanol })\end{array}$ & $\begin{array}{l}5 \cdot 09 \pm 0 \cdot 30^{a} \\
(n=6) \\
6 \cdot 08 \pm 0 \cdot 78^{a} \\
(n=6)\end{array}$ & $\begin{array}{l}6 \cdot 83 \pm 0 \cdot 53^{a} \\
(n=6) \\
5 \cdot 22 \pm 0 \cdot 50^{a} \\
(n=6)\end{array}$ & $\begin{array}{l}6 \cdot 90 \pm 0 \cdot 62^{a} \\
(n=6) \\
6 \cdot 82 \pm 0 \cdot 92^{a} \\
(n=6)\end{array}$ \\
\hline \multicolumn{4}{|c|}{ High carbohydrate-low protein } \\
\hline $\begin{array}{l}\text { IB } \\
\left(\mathrm{H}_{2} \mathrm{O}\right) \\
\text { IIB } \\
(+15 \% \text { ethanol })\end{array}$ & $\begin{array}{l}5 \cdot 72 \pm 0 \cdot 42^{a} \\
(n=6) \\
4 \cdot 19 \pm 0 \cdot 25^{b} \\
(n=6)\end{array}$ & $\begin{array}{l}5 \cdot 96 \pm 0 \cdot 50^{a} \\
(n=6) \\
4 \cdot 37 \pm 0 \cdot 27^{b} \\
(n=6)\end{array}$ & $\begin{array}{l}7 \cdot 24 \pm 0 \cdot 41^{a} \\
(n=6) \\
5 \cdot 24 \pm 0 \cdot 37^{b} \\
(n=6)\end{array}$ \\
\hline
\end{tabular}

Results shown are the mean \pm SE. For each column, means not sharing a common superscript letter differ significantly $(p<0.05)$. 
height suggest at this period the maintenance of total microvillus surface in these experimental conditions. In contrast, a significant decrease in the protein content was observed when ethanol consumption was associated with the high carbohydrate-low protein diet (IIB). The brush border protein yield was very similar in all groups. Thus, the average brush border protein yield was at two, four and eight weeks respectively $3.20 \%$, $4.00 \%$ and $3.80 \%$ in group IA; $3.70 \%, 3.80 \%$ and $4.00 \%$ in group IIA; $3.80 \%, 3.40 \%$ and $3.80 \%$ in group IB and $2.90 \%, 3.30 \%$ and $3.30 \%$ in group IIB.

\section{EFFECTS OF DIETS AND ETHANOL ON ENZYME}

ACTIVITIES OF BRUSH BORDER MEMBRANES

The degree of purification for a given brush border enzyme did not vary significantly between the different groups or for each group at the various periods tested.

Brush border sucrase, maltase, and lactase activities were significantly increased in rats fed the high carbohydrate-low protein diet (IB) in comparison with the rats receiving the normal diet (IA). For both sucrase and maltase activities, the stimulation was maximal after two weeks of feeding and remained unchanged during the following weeks (Figure, $a$ and b). Lactase activity already enhanced by two weeks increased until the fourth week (Figure, c). In contrast, aminopeptidase activity showed no change during the first four weeks of feeding the high carbohydrate-low protein diet. After this period, aminopeptidase activity dropped significantly (Figure, d).

When ethanol was given to the rats fed the normal diet (IIA), very similar results to those observed with the high carbohydrate-low protein diet (IB) were obtained concerning the evolution of the activities of the disaccharidases in the brush border membranes, although major differences were obvious in the timing of disaccharidase stimulation. Thus, it was only after four weeks of alcohol ingestion that a significant increase of sucrase, maltase, and lactase activity could be detected. Thereafter, the level of activity reached by the disaccharidases was not different from that found in the rats receiving the high carbohydrate-low protein diet (IB) (Figure, a, b, c). Concerning aminopeptidase activity (Figure, d), chronic alcohol ingestion associated with the normal diet (IIA) provoked no significant modification in this enzyme activity during the whole experimental period tested

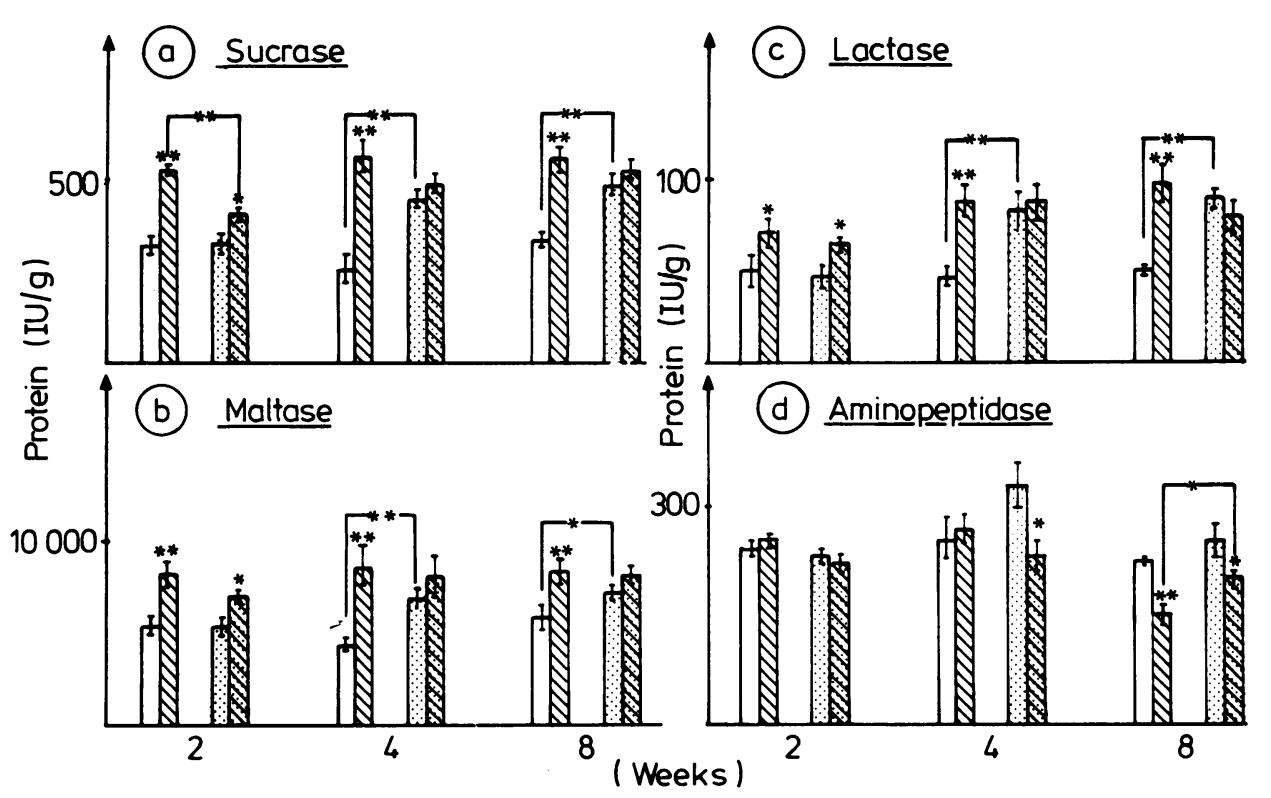

Figure Specific activities of jejunal enzymes (means $\pm S E$ ) in the brush border membranes of rats fed a normal or a high carbohydrate-low protein diet given in association with water $(\square, \mathbb{N})$ and of rats fed a normal or a high carbohydrate-low protein diet given in association with $15 \%$ ethanol (, ). This study was performed after two, four and eight weeks of feeding. The $p$ value symbols without connecting lines refer to comparison of adjacent means. ${ }^{*} p<0 \cdot 01 .{ }^{* *} p<0 \cdot 001$. $1 \mathrm{IU}=1 \mu \mathrm{mol}$ of product formed per minute at $37^{\circ} \mathrm{C}$. 
when compared with the rats receiving the normal $\operatorname{diet}$ (IA).

The association of the high carbohydrate-low protein diet with alcohol ingestion (IIB) provoked a stimulation of the disaccharidase activities obvious by two weeks of feeding. This stimulation was, however, less important than that obtained, especially for sucrase (Figure, a), in animals receiving water (group IIA). By four weeks similar values were obtained for the disaccharidases in the brush border membranes of rats fed either the normal diet associated with alcohol (IIA) or the high carbohydrate-low protein diet (IB and IIB). The administration of alcohol with the high carbohydrate-low protein diet (IIB) depressed aminopeptidase activity after four weeks when compared with the activity measured in the brush border membrane of the rat fed the normal diet with alcohol (IIA) (Figure, d). Alcohol associated with the high carbohydrate-low protein diet (IIB), however, provoked no modification in this activity when compared with the rats of group IA.

\section{Discussion}

As the amount of brush border proteins, the brush border protein yield, and the degree of purification were very similar, especially for the groups IA, IIA and IB throughout the experimental period, we can assume that modifications in the activities of the brush border enzymes did not derive from differences occurring at the level of membrane preparation.

When the data were examined to determine the response of brush border enzymes to prolonged alcohol ingestion in association with a normal diet or with a high carbohydrate-low protein diet, the following statements could be made.

During the first two weeks, alcohol ingestion did not modify the activities of the disaccharidases and aminopeptidase in the brush border membrane. Furthermore, during this period ethanol consumption lowered sucrase adaptation to the high carbohydrate diet. At four weeks, however, and thereafter during the whole experimental period, alcohol ingestion led to a stimulation of the brush border disaccharidase activities similar to the one provoked by feeding the high carbohydrate diet alone. There was no synergistic effect between alcohol consumption and the diet as alcohol alone was able to stimulate the disaccharidase activities to a level which could not be further increased by feeding the high carbohydrate diet. Alcohol seemed also to exert a protective effect on aminopeptidase activity, as this enzyme activity was less decreased when the feeding of the high carbohydrate-low protein diet was associated with alcohol consumption.

It has been previously shown that ethanol consumption depressed intestinal disaccharidase, alklaline phosphatase, and aminopeptidase activities. ${ }^{134}$ In contrast, normal intestinal lactase level in alcoholics ${ }^{15}$ and normal sucrase and lactase levels in the jejunum of monkeys after several months of alcohol consumption were recently reported. ${ }^{16}$ In the present report we give evidence of an increase of the brush border disaccharidase activities in the jejunum of rats receiving alcohol for several weeks. Where the comparative effects of the high carbohydrate diet and alcohol consumption on the enzyme activities of the brush border membrane are concerned a major difference was noted in the lag of time-response of the disaccharidases. The high carbohydrate-low protein diet provoked a rapid stimulation of sucrase and maltase activities; this stimulation reached already its maximum two weeks after the initiation of this diet. It is well-documented that adaptation of intestinal sucrase and maltase activities occurs a few hours after feeding a high carbohydrate diet ${ }^{17-22}$ and that dietary carbohydrate stimulates these enzyme activities mainly in the immature cells of the lower part of the villus ${ }^{21} 22$ partly by inducing synthesis of enzyme molecules. ${ }^{21}$ In contrast, alcohol did not provoke an early rise in disaccharidase activity and it was only by four weeks that alcohol consumption caused a stimulation of the disaccharidases similar to the one produced by the high carbohydrate-low protein diet alone. As the stimulatory effects of alcohol on intestinal disaccharidase activity occurred after a delay of several weeks, it is likely that alcohol exerts a mainly indirect effect on the regulation of disaccharidase activity. It can be suggested that this effect could secondarily result from altered pancreatic secretory functions ${ }^{72324}$ or from changes in plasma insulin level $^{25}$ provoked by chronic alcohol consumption, leading to modifications in the turnover and activity of brush border enzymes. ${ }^{26-28}$ The present report also shows that the activity of all the disaccharidases including lactase is enhanced in the brush border membrane of the rats fed the high carbohydrate-low protein diet. These results conflict with previous findings which show that lactase activity was not modified after feeding a high carbohydrate diet. ${ }^{1821}$ The discrepancy between these results may originate from the fact that the studies reporting no modification of lactase activity have been performed after a starvation period of 48 hours, and that enzyme activities have been determined only a few hours after the initiation of refeeding the high carbohydrate diet. In this regard, it has been demonstrated that starvation caused increased specific activity of lactase $\mathrm{e}^{29}$ and that a high carbohydrate diet 
administered to rats for several days might enhance lactase activity in the jejunum of rats. ${ }^{30}$ In our experimental conditions maximum activity for lactase was reached only by four weeks after initiation of the high carbohydrate-low protein diet; this suggests that regulation of lactase activity in the jejunum proceeds by other machanisms than those involved in the regulation of sucrase or maltase activities. $^{31-33}$

This study was supported by INSERM and by DGRST (Grant No $81 \mathrm{~L}$ 1312). We would like to acknowledge the excellent technical assistance of Miss Francine Gosse and Mr Michel Galluser.

\section{References}

1 Baraona E, Pirola RC, Lieber CS. Small intestinal damage and changes in cell population produced by ethanol ingestion in the rat. Gastroenterology 1974; 66: 226-34.

2 Greene HG, Stifel FB, Herman RH, Herman JF, Rosensweig NS. Ethanol induced inhibition of human intestinal enzyme activities: reversal by folic acid. Gastroenterology 1974; 67: 434-40.

3 Perlow W, Baraona E, Lieber CS. Symptomatic intestinal disaccharidase deficiency in alcoholics. Gastroenterology 1977; 72: 680-4.

4 Eloy R, Battinger F, Bignon JY, Ananna A, Grenier JF. Intestinal brush border enzymes and chronic alcohol ingestion. Experimental study in rats. Res Exp Med 1979; 175: 257-69.

5 Mezey E, Halsted $\mathrm{CH}$. Effects of alcohol on gastrointestinal and pancreatic function in alcoholics. In: Gastinean CF, Darby WJ, Turner TB, eds. Fermented food beverages in nutrition. New York: Academic Press 1979: 277-302.

6 Mezey E, Jow E, Slavin R, Iobon F. Pancreatic function and intestinal absorption in chronic alcoholism. Gastroenterology 1970; 59: 657-65.

7 Sarles H. Alcool et tractus digestif. Pluralité des mécanismes d'action. Biol Gastroenterol 1976; 9: 93-8.

8 Jian R, Modigliani R. Absorption intestinale et alcoolisme chez l'homme. Gastroenterol Clin Biol 1980; 4: 577-87.

9 Schmitz J, Preiser H, Maestracci D, Ghosh BK, Cerda JJ, Crane RK. Purification of the human intestinal brush border membrane. Biochim Biophys Acta 1973; 92: 305-11.

10 Raul F, Simon PM, Kedinger M, Grenier JF, Haffen K. Separation and characterization of intestinal brush border enzymes in adult rats and in suckling rats under normal conditions and after hydrocortisone injections. Enzyme 1978; 23: 89-97.
11 Messer M, Dahlqvist A. A one step ultramicromethod for the assay of intestinal disaccharidases. Ann Biochem Biophys 1966; 14: 376-92.

12 Maroux S. Louvard D, Baratti J. The aminopeptidase from hog intestinal brush border. Biochim Biophys Acta 1973; 321: 282-95.

13 Koldovsky O, Asp NG, Dahlqvist A. A method for the separate assay of 'neutral' and 'acid' $\beta$-galactosidase in homogenates of rat small intestinal mucosa. Anal Biochem 1969; 27: 409-18.

14 Lowry OH, Rosebrough NJ, Farr AL, Randall RJ. Protein measurement with the Folin phenol reagent. $J$ Biol Chem 1951; 193: 265-75.

15 Seetharam B, Perrillo R, Alpers DH. Effect of pancreatic proteases on intestinal lactase activity. Gastroenterology 1980; 79: 827-32.

16 Romero JJ, Tamura $\mathrm{T}$, Halsted $\mathrm{CH}$. Intestinal absorption of $\left[{ }^{3} \mathrm{H}\right]$ folic acid in the chronic alcoholic monkey. Gastroenterology 1981; 80: 99-102.

17 Blair DGR, Yakimets W, Tuba J. Rat intestinal sucrase. II. The effects of rat age and sex and of diet on sucrase activity. Can J Biochem Physiol 1963; 41: 917-29.

18 Deren JJ, Broitman SA, Zamcheck N. Effect of diet upon intestinal disaccharidases and disaccharide absorption. J Clin Invest 1967; 46: 186-95.

19 Rosensweig NS, Herman RM. Time response of jejunal sucrase and maltase activity to a high sucrose diet in normal man. Gastroenterology 1969; 56: 500-5.

20 Kimura T, Seto A, Yoshida A. Effect of diets on intestinal disaccharidase and leucine aminopeptidase activities in refed rats. $J$ Nutr 1978; 108: 1087-97.

21 Raul F, Simon PM, Kedinger M, Grenier JF, Haffen $K$. Effect of sucrose refeeding on disaccharidase and aminopeptidase activities of intestinal villus and crypt cells in adult rats. Evidence for a sucrose dependent induction of sucrase in the crypt cells. Biochim Biophys Acta 1980; 630: 1-9.

22 Ulshen MH, Grand RJ. Site of substrate stimulation of jejunal sucrase in the rat. J Clin Invest 1979; 64: 1097-102.

23 Sarles H, Tiscornia O, Palasciano G, Brasca A, Hage G, Devaux MA, Gullo L. Effects of chronic intragastric ethanol administration on canine exocrine pancreatic secretion. Scand J Gastroenterol 1972; 8: 85-96.

24 Tiscornia O, Gullo L, Sarles H, Devaux MA, Michel $\mathrm{G}$, Grimaud $\mathrm{R}$. The inhibition of canine exocrine pancreatic secretion by intravenous ethanol. Digestion 1973; 9: 231-40.

25 Potter DE, Morris JW. Ethanol induced changes in plasma glucose, insulin and glucagon in fed and fasted rats. Experientia 1980; 36: 1003-4.

26 Alpers DH, Tedesco FJ. The possible role of pancreatic proteases in the turnover of intestinal brush border protein. Biochim Biophys Acta 1975; 401: 28-40.

27 Caspary WF, Winckler K, Lankish PG Creutzfeldt W. Influence of exocrine and endocrine pancreatic function on intestinal brush border enzymatic activities. Gut 1975; 16: 89-92.

28 Dubois RS, Gotlin RW, Rodgerson DO. Lack of dietary regulation of jejunal glycolytic enzymes and 
disaccharidases in obesity: the role of insulin. Gastroenterology 1975; 68: 461-5.

29 McNeill LK, Hamilton JR. The effect of fasting on disaccharidase activity in the rat small intestine. Peaiatrics 1971; 47: 65-72.

30 McCarthy DM, Nicholson JA, Kim YS. Intestinal enzyme adaptation to normal diets of different composition. Am J Physiol 1980; 239: G6445-51.

31 Bolin TD, McKern A, Davis AE. The effect of diet on lactase activity in the rat. Gastroenterology 1971; 60: 432-7.

32 Sahi T. Dietary lactose and the aetiology of human small intestinal hypolactasia. Gut 1978; 19: 1074-86.

33 Bustamante S, Gasparo M, Kendall K, Coates P, Brown S, Somawane B, Koldovsky O. Increased activity of rat intestinal lactase due to increased intake of $\alpha$-saccharides (starch, sucrose) in isocaloric diets. $J$ Nutr 1981; 111: 943-53. 